\title{
DOES TIMING MATTER FOR THE DETERMINANTS OF IPO SHORT-TERM RETURNS? EVIDENCE FROM THE TOP EMERGING MARKETS
}

\begin{abstract}
The study examined the short-term price behavior of initial public offerings (IPOs) of equities listed on the top emerging market exchanges during the period from 2005 to 2012 . We investigated whether underpricing could be explained with models based on stakeholder rationality and those concerning behavioral factors. There were extremely high initial, two- and four-week returns in the three top emerging markets during the sample period. The results documented the existence of significant differences in IPO short-term returns between initial equity issues offered in hot- versus cold-and-neutral markets. It was also found that the amount of money left on the table during initial public offerings was related most to the uncertainty, signaling and timing proxies. The study showed that the explanations for high initial returns were, to some extent, influenced by IPO timing.
\end{abstract}

Key words: initial public offerings, underpricing, information asymmetry, signalling.

\section{INTRODUCTION}

Numerous studies have investigated initial public offerings (IPOs), as they play a highly important role in company financing. Initially, this research mostly concerned the US market, but in the recent years there has been increased attention paid to many other markets as well. One of the phenomena documented for IPOs is short-term underpricing, whereby the first market price was, on average, significantly higher than the offer price. As the total money left on the table due to underpricing has been documented to be substantial, the academic community has examined not only the underpricing level but also the reasons for this anomaly.

The present study continues this intriguing research discussion on the underpricing of initial public offerings. The research has three major objectives. First, to investigate the level of first-day and short-term returns for the three top

\footnotetext{
" Ph.D., Poznan University of Economics, Department of Corporate Finance.

** Ph.D., Poznan University of Economics, Department of Corporate Finance.
} 
emerging markets, for which we use a contemporaneous sample of 1,845 IPOs from the three top emerging markets for the period of 2005 to 2012. Second, to compare IPOs in the hot, and neutral-and-cold markets and to analyze the differences in the underpricing level in these market regimes. Third, to explain the level of recorded underpricing with models derived from the information asymmetry theory and models connected with investor sentiment background, also in the context of different market regimes.

We try to explain the underpricing level in the top emerging markets with investor sentiment factors in order to advance the argument that IPO markets were affected by behavioral factors. The paper also includes empirical studies concerning the asymmetric information theories that point out that investors should be paid for the high level of uncertainty at issuing time. Here, the underpricing is seen as a kind of fee for such a risk. We also explore the second direction of theories under the information asymmetry, which emphasizes the signaling role of underpricing under the IPO underpricing signaling hypothesis.

The rest of the paper is organized as follows. Section 2 introduces some of the literature on initial public offerings. Section 3 discusses the data, presents descriptive statistics and defines hot, and neutral-and-cold issue subsamples. Section 4 describes the methodology. Section 5 documents empirical evidence on underpricing and discusses the differences between the amount of money left on the table at issuing in hot, and neutral-and-cold market regimes. The results of the analysis of the relationship between underpricing and proxies for pre-IPO uncertainty, around the issue of investor sentiment and signaling games constitute the content of section 6 . Section 7 summarizes the findings of the study and concludes.

\section{REVIEW OF THE PREVIOUS STUDIES}

Past studies have documented notable underpricing for IPOs, although the degree of underpricing has varied from country to country and changed over time and has been reported by Ibbotson [1975], Loughran and Ritter [1995], Rajan and Servaes [1997], Ljungqvist [1997], Ghosh [2005], Lin, Lee and Lee [2008], or Lee, Kuo and Yen [2011], among others.

There have been many theoretical and empirical studies on IPOs that aimed to explain the differences in the reported levels of initial returns. One explanation is connected with the hot-issue phenomenon. IPO markets seem to be very cyclical and many issuers appear to take advantage of the ,window of opportunity", when investors are highly optimistic. Managers can fool investors by timing initial offerings in order to make the most of optimistic valuations 
[Baker and Wulgler 2002]. Lowry and Schwert [2002] showed that after periods of extremely high initial returns, there were usually higher IPO volumes observed. This line of short-term explanations for IPO price behavior emphasizes the role of investor sentiment and bounded rationality, which can be of especially high importance in hot markets [Oehler, Rummer and Smith 2008; Derrien, 2005]. We define short- and long-term market-related variables as proxies for investor sentiment and market climate and we also check the relationship between IPO underpricing and the previous price behavior on the IPO market in order to analyze the importance of the irrational behavior towards new offerings that was observed in the recent past due to market fads.

The second main research stream was based on the asymmetric information models which attempted to rationalize the underpricing anomaly. Here, many research streams appeared. One was connected with the Rock model [1986] and the winner's curse hypothesis. Underpricing was supposed to be a lure to attract uninformed investors, as the uncertainty about the intrinsic value of the firm and its fundamentals is usually high around issue time. Because of the ex-ante uncertainty and adverse selection bias, the IPO underpricing level must be very high to compensate for the risk, even for uniformed inventors. When ex-ante uncertainty about the true value of the firm is higher, the underpricing is also expected to be substantial [Beatty and Ritter 1986]. The problem with the application of the Rock model is that the ex-ante uncertainty is usually unobservable and impossible to measure directly. Therefore, following the literature, we used the proxy of the volatility of daily returns in the early aftermarket [Ritter 1984; McGuinness 1992]. We also involved other proxies of uncertainty, the size of the firm being one of them. We expected small companies to display a higher initial return, in line with the higher degree of ex-ante uncertainty about the company's prospects. Also the size of the issue was included as an alternative proxy for uncertainty. Market investors and security analysts usually try to decrease the uncertainty level by analyzing financial ratios under the assumption that they are reliable and able to reveal some information about the firm's situation and its prospects for the future. Following this, some measures of profitability were applied. On the one hand, an investment in a „better" company's shares at flotation should involve less risk. On the other, many earnings management practices before going public have been revealed in practice, which can result in a higher risk level connected with obfuscating the firm performance. It was described in previous studies by Teoh, Welch and Wong [1998], Pastor-Llorca and Poveda-Fuentes [2006], Roosenboom, van der Goot and Mertens [2003]. Rapid changes in profitability measures may arouse suspicion about 'window dressing' techniques. Next, as more established firms are supposed to be valued more accurately, we observed the effect of the company's age at the time of issue on the level of underpricing. 
In the signaling approach, underpricing is motivated by the idea to deliberately and voluntarily signal the intrinsic IPO firm's value [Allen and Faulhaber 1989]. Underpricing may act as a decoy to achieve higher offer prices in subsequent, seasoned, equity offerings [Jegadeesh, Weinstein and Welch 1993]. Harris and Raviv [1990], or Nachman and Noe [1994] proposed leverage as conveying information to outsiders. The more debt a firm has in its capital structure prior to the IPO, the more positive a signal to investors. The high leverage is perceived as proof of a firm's credibility and quality, as it introduces strong budget constraints on managers and limits their latitude to control cash flow. To test these explanations of underpricing, focusing on the signaling hypothesis, we introduced the leverage ratio as an explanatory variable to the model.

\section{DATA AND SAMPLE DESCRIPTION}

The data sources for the IPO sample were obtained from the Capital IQ Database. Markets were classified according to the MSCI Market Classification Framework (November 2013). The sample consisted of initial public offerings completed during 2005-2012 by companies from the three biggest emerging IPO markets: China, South Korea and India on the Shenzhen Stock Exchange (SZSE), Shanghai Stock Exchange (SHSE), KOSDAQ Exchange (KOSDAQ), Korea Stock Exchange (KOSE), the Bombay Stock Exchange (BSE) and the National Stock Exchange of India (NSE). The main sample consisted of 1,845 initial equity offerings, with proceeds totaling US $\$ 229,721$ million. The data for these IPOs, information about stock prices, and financial statement information were not always uniform and comprehensive so some limitations had to be put into the subsequent research. Table 1 provides the detailed differences in the scope of offerings between IPOs that went public in the three top emerging markets (the main sample) and listings from the whole world, developed markets (Europe, Australasia and Far East Developed Markets and EAFE countries according to MSCI classification) or IPOs in all emerging markets. IPOs from the three top emerging markets made up of 16 percent of offerings conducted worldwide and as many as 61 percent of transactions from all emerging markets.

The equity market environment changed rapidly and IPO activity seemed to be highly cyclical. Figure 1 plots the quarterly gross proceeds from IPOs listed on the top emerging markets together with the average quarterly level of the MSCI World Index and the MSCI Emerging Markets Index. The first peak of IPO activity occurred in the last quarter of 2007, ending a period of bull market. The last quarter of 2008 and the first quarters of 2009 reflected the huge worldwide market downturn, with a considerable drop in IPO activity. After the rapid change in investor sentiment, the biggest peak of new listings in the top emerging markets occurred in the second quarter of 2010. 
Table 1. Sample distribution across developed and emerging markets

\begin{tabular}{|c|c|c|c|c|c|c|c|c|c|}
\hline & $2005-12$ & 2005 & 2006 & 2007 & 2008 & 2009 & 2010 & 2011 & 2012 \\
\hline \multicolumn{10}{|l|}{ Panel A: World } \\
\hline Number of IPOs & 11,539 & 1,581 & 1,837 & 2,250 & 988 & 732 & 1,626 & 1,477 & 1,048 \\
\hline Average proceeds [USDmm] & 133 & 110 & 131 & 149 & 100 & 156 & 162 & 117 & 124 \\
\hline Total proceeds [USDbn] & 1,514 & 173 & 241 & 332 & 98 & 113 & 262 & 167 & 128 \\
\hline \multicolumn{10}{|c|}{ Panel B: Europe, Australasia and Far East Developed Markets } \\
\hline Number of IPOs & 3,106 & 477 & 647 & 672 & 216 & 147 & 349 & 337 & 261 \\
\hline Average proceeds [USDmm] & 154 & 130 & 146 & 156 & 82 & 208 & 252 & 143 & 120 \\
\hline Total proceeds [USDbn] & 475 & 62 & 94 & 104 & 18 & 30 & 88 & 48 & 31 \\
\hline$\%$ of total world IPOs [\%] & 27 & 30 & 35 & 30 & 22 & 20 & 21 & 23 & 25 \\
\hline$\%$ of total world proceeds [\%] & 31 & 36 & 39 & 31 & 18 & 27 & 33 & 29 & 24 \\
\hline \multicolumn{10}{|l|}{ Panel C: Emerging Markets } \\
\hline Number of IPOs & 3,006 & 232 & 269 & 471 & 228 & 244 & 646 & 588 & 328 \\
\hline Average proceeds [USDmm] & 136 & 67 & 178 & 137 & 115 & 196 & 167 & 106 & 105 \\
\hline Total proceeds [USDbn] & 401 & 16 & 48 & 64 & 26 & 48 & 107 & 58 & 34 \\
\hline$\%$ of total world IPOs [\%] & 26 & 15 & 15 & 21 & 23 & 33 & 40 & 40 & 31 \\
\hline$\%$ of total world proceeds [\%] & 26 & 9 & 20 & 19 & 27 & 42 & 41 & 35 & 27 \\
\hline \multicolumn{10}{|c|}{ Panel D: Chinese, Indian and South Korean Markets } \\
\hline Number of IPOs & 1,845 & 65 & 136 & 262 & 142 & 172 & 480 & 388 & 200 \\
\hline Average proceeds [USDmm] & 125 & 50 & 79 & 108 & 105 & 174 & 166 & 119 & 86 \\
\hline Total proceeds [USDbn] & 230 & 3 & 11 & 28 & 15 & 30 & 80 & 46 & 17 \\
\hline$\%$ of total world IPOs [\%] & 16 & 4 & 7 & 12 & 14 & 23 & 30 & 26 & 19 \\
\hline$\%$ of total world proceeds [\%] & 15 & 2 & 4 & 8 & 15 & 26 & 30 & 28 & 13 \\
\hline
\end{tabular}

Source: own calculations.

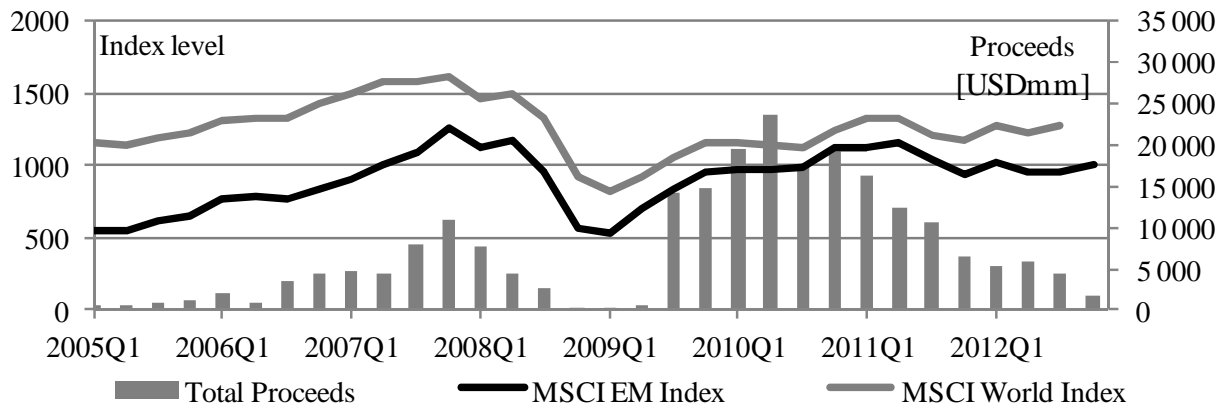

Figure 1. IPO activity in the top emerging markets, and the world and emerging markets indexes during the sample period of 2005 to 2012

Source: own calculations. 


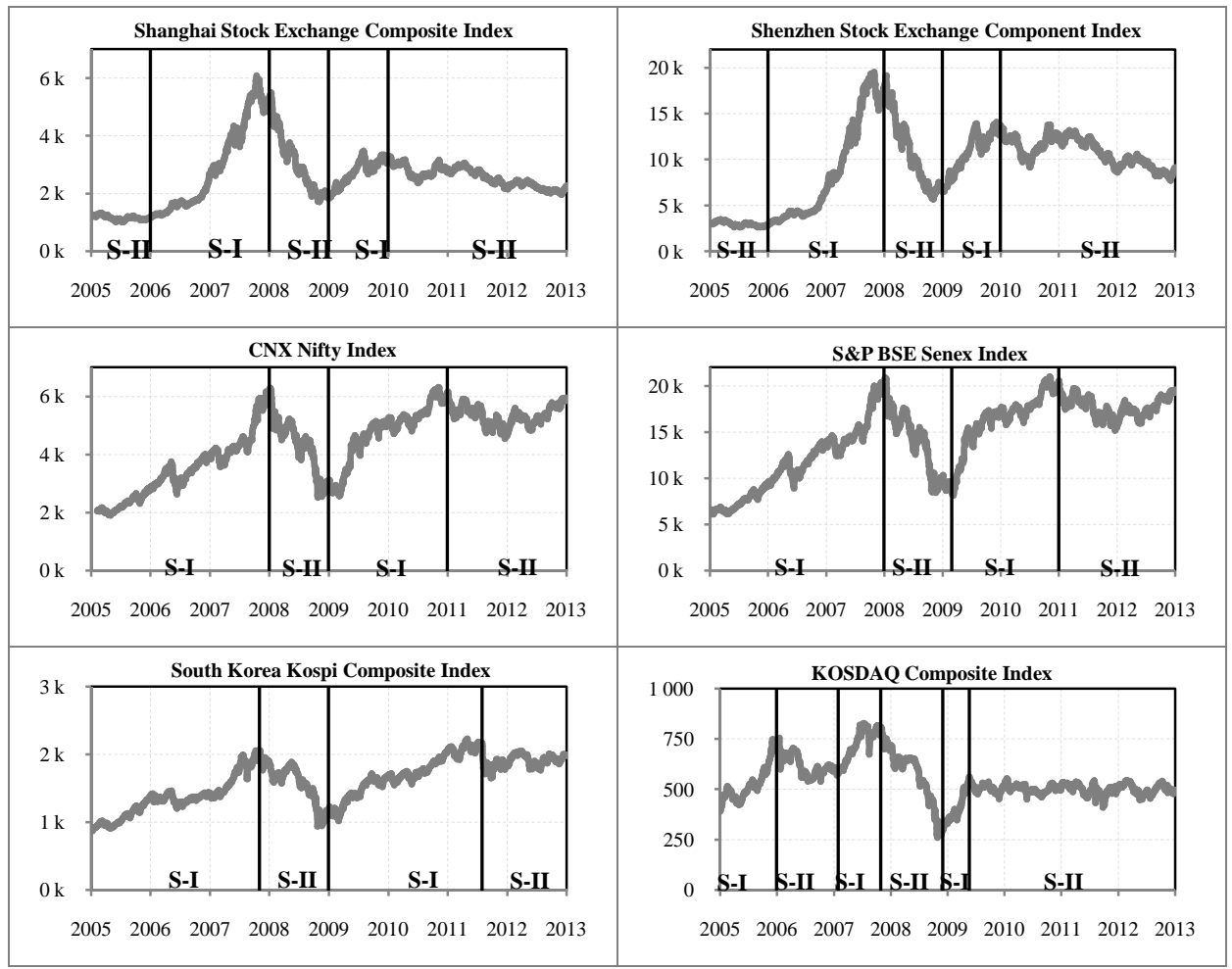

Figure 2 a-f. Hot (S-I), neutral-and-cold (S-II) periods during 2005-2012

Source: own calculations.

We then formed two subsamples for the top emerging market IPOs in order to observe the market reaction during the hot versus neutral-and-cold market regimes. The period from January 2005 to December 2012 for each of the selected six exchanges from three top emerging countries was cut into shorter periods in order to reflect the accelerating or decelerating trends in the pricing of the main index for each exchange. The cut off points for the subperiods were a somewhat arbitrary decision.

We plotted the results of the procedure of splitting IPOs into the time-varied samples in Figure 2 on Charts from a to $\mathrm{f}$. The first sample (Sample I) represented a hot market. The second sample (Sample II) served as a representative of a cold-and-neutral market.

Then, we combined each IPO with the information about the bear or bull market at the time of issuing, which resulted in the division of the main IPO sample into two subgroups. The number of companies listed on exchanges from the top emerging markets in hot market conditions totaled 656 in comparison to 1,189 IPOs in lukewarm markets. 
Table 2. Financial characteristics of IPO firms issuing during hot periods (Sample I) and neutral periods (Sample II)

\begin{tabular}{lccc}
\hline Characteristic & Mean & Median & Observations \\
\hline Panel A: Sample I (hot periods) & & & \\
Assets & 293 USDmm & 46 USDmm & 610 \\
Proceeds & 76 USDmm & 34 USDmm & 626 \\
Return on assets & $10 \%$ & $9 \%$ & 610 \\
Operating return on sales & $16 \%$ & $14 \%$ & 580 \\
Net income change & 1.65 & 1.36 & 611 \\
Sales change & 1.42 & 1.30 & 603 \\
Company age & 19 years & 13 years & 557 \\
Leverage & $28 \%$ & $29 \%$ & 587 \\
Panel B: Sample II (cold-and-neutral periods) & & \\
Assets & 116 USDmm & 61 USDmm & 1,117 \\
Proceeds & 97 USDmm & 74 USDmm & 1,138 \\
Return on assets & $14 \%$ & $13 \%$ & 1,117 \\
Operating return on sales & $19 \%$ & $17 \%$ & 1,101 \\
Net income change & 1.22 & 1.18 & 1,117 \\
Sales change & 1.27 & 1.24 & 1,107 \\
Company age & 16 years & 12 years & 928 \\
Leverage & $22 \%$ & $20 \%$ & 1.007 \\
\hline
\end{tabular}

Source: own calculations.

The summary statistics about the subsamples are reported in Table 2. It gives the basic understanding of the characteristics of the IPO firms around the time of issue. It presents the size, calculated in two ways: first, the size of the issuing company measured by total assets at the end of the year prior to the date of going public, and second, the size of the issue which was measured with the gross proceeds from the equity issue. The median firm that began to quote on the top emerging markets during bullish times was slightly smaller in comparison to firms issuing in neutral-and-cold market. However, the mean book asset value was almost two and a half times bigger for hot-market IPOs. Mean and median hot market issues were smaller than cold-and-neutral market offerings.

Next, four characteristics give a brief glimpse into the pre-issue profitability of IPO companies. First, we measured the pre-issue return on assets as the relation of the net income and total assets of the year prior to the date of going public. Next, operating return on sales was reported as earnings before interest and tax to revenues from the year prior to the date of going public. Finally, we observed the change of net income and the change in sales, both expressed as the ratio of the value from the IPO year to the value from the year prior to the 
IPO year. Firms that went public during the cold-and-neutral periods had higher profitability in the year prior to the initial offer. However, the increase in income and sales when firms began to quote was higher for hot-market issuers. Firms going public in the bull market were also those for which the increase of net income at flotation was higher that the growth of sales value. This was not observed for cold-and-neutral market issuers, where the increase in sales was higher that the corresponding increase in net income.

The average age of hot-market issuers in Sample I was 19 years (with a median of 13 years), in comparison to 16 years for issuers of the cold-and-neutral periods (with a median of 12 years). The leverage was measured as the ratio of total debt to total assets in the year prior to the IPO date. Hot-issuers were much more leveraged prior to the offering in comparison to firms issuing during a bear market.

\section{METHODOLOGY}

In the first step, initial IPO return was estimated. It was defined as the percentage change between the offer price and the first closing market price of the IPO, which was expressed as:

$$
I R_{i, t}=\frac{I P_{i}}{P O_{i}}-1
$$

where:

$I P_{i} \quad-\quad$ was the first aftermarket price for IPO $i$ observed not later than on the second day in the aftermarket,

$\mathrm{PO}_{i}-\quad$ was the offer price for IPO $i$.

We also observed the short-term returns during the first two and four weeks in the aftermarket. The short-term performance was evaluated by:

$$
S R_{i, t}=\frac{P_{i, t}}{P O_{i}}-1
$$

where:

$P_{i, t}-\quad$ was the aftermarket price for IPO $i$ observed on the 14 th and $28^{\text {th }}$ day in the aftermarket for two- and four-week returns, respectively.

The null hypothesis that the average initial and short-term return in each subsample was equal to zero was tested with the parametric Student t-test 
and the non-parametric Wilcoxon signed-rank test. We also employed the Jarque-Bera test to check normal distribution. The differences in returns between Sample I and Sample II were tested with the use of the Student t-test and the Mann-Whitney U-test. The statistical significance was presented according to conventional confidence levels (1\%, 5\% and 10\%).

In the next step, we evaluated the relationship between the initial returns and different explanatory variables (see Table 3 ) through regressions.

Table 3. Explanatory variables for regressions

\begin{tabular}{ll}
\hline Proxies & \multicolumn{1}{c}{ Description } \\
\hline Panel A: Proxies for the ex-ante uncertainty \\
PROC & $\begin{array}{l}\text { Size of the issue, calculated as total proceeds from the initial public offering } \\
\text { Size of the company, calculated as the book value of assets at the end of the } \\
\text { year prior to the IPO date }\end{array}$ \\
Net profitability of firm, calculated as the return on assets, so net income \\
divided by total assets in the year prior to the IPO date
\end{tabular}

Panel B: Proxies for signaling games

SEO A dummy coded 1 if the IPO firm offered a seasoned equity offering in he subsequent 2 year after IPO

LEV Leverage, calculated as the total debt divided by total assets at the end of the year prior to the IPO date

\section{Panel C: Proxies for investor sentiment}

PREV_UND Previous underpricing experienced by preceding IPO firms, calculated as the mean of underpricing for all top emerging market IPO firms for 6 months prior to the IPO date

WORLD_LR Pre-market long-run world performance of equity markets, calculated as the mean return on MSCI World Index during two quarters before the IPO date

REGION_SR Pre-market short-run performance of equity markets in the region, measured as the mean return in the region in the period of 20 trading days before and after the IPO date; the regional index was calculated as equally weighted. average of returns based on the main indexes from each exchange

TIMING A dummy coded 1 if listed in hot markets, an additional explanatory variable for the whole sample regression

Source: own calculations. 
We ran four regressions. The first two regressions (OLS_1 and OLS_2), presented only the statistically significant variables and variables with a significance just below the required confidence levels. The next two regressions (OLS_3 and OLS_4) combined all variables taken into account at the beginning of the empirical work. The regressions differed also in the way the outliers were treated. The procedure of trimming extreme values on the basis of statistical computing in the R software environment was adopted in OLS_1 and OLS_3. The procedure of the leave-one-out deletion was based on the DFBETAS for; each model variable, DFFITS, covariance ratios, Cook's distances and the diagonal elements of the hat matrix. The variables in regressions OLS_2 and OLS_4 were Winsorized with the lower and upper bounds calculated as the mean minus 2 times the standard deviation, and the mean plus 2 times the standard deviation, respectively.

\section{SHORT-TERM RETURNS}

The objective of this section was to analyze the underpricing phenomenon on the top emerging markets in general. Table 4 reports the initial, two-week and four-week returns for China India and South Korea.

Table 4. Short-term returns the top emerging economies

\begin{tabular}{lcccc}
\hline & All markets & China & India & $\begin{array}{c}\text { South } \\
\text { Korea }\end{array}$ \\
\hline Panel A: Initial returns (underpricing) & & & & \\
Mean [\%] & 47.88 & 51.03 & 21.44 & 36.11 \\
Median [\%] & 32.19 & 34.18 & 15.80 & 21.55 \\
Standard deviation [\%] & 55.42 & 57.80 & 32.86 & 43.25 \\
Observations & 1,152 & 916 & 8 & 228 \\
\hline Panel B: Two-week returns & & & & \\
Mean [\%] & 38.40 & 44.73 & 23.47 & 27.13 \\
Median [\%] & 24.41 & 29.59 & 10.01 & 9.85 \\
Standard deviation [\%] & 53.04 & 53.19 & 44.09 & 54.32 \\
Observations & 1,498 & 1,001 & 200 & 297 \\
\hline Panel C: Four-week returns & & & & \\
Mean [\%] & 35.50 & 43.98 & 23.88 & 19.63 \\
Median [\%] & 20.19 & 28.09 & 12.27 & 3.40 \\
Standard deviation [\%] & 54.46 & 55.01 & 47.50 & 53.29 \\
Observations & 1,614 & 1,001 & 293 & 320 \\
\hline
\end{tabular}

Source: own calculations. 
The initial underpricing for the top emerging markets seem in fact substantial. The highest underpricing was reported for Chinese IPOs with the mean (median) equal to 51.03 percent (34.18). The price in terms of two- and four week returns also rose most in China.

Figure 3 shows the first-day return distributions of underpricing during hot, and cold-and-neutral markets. The details about average initial, two- and four-week returns for both subsamples were reported in Table 5.

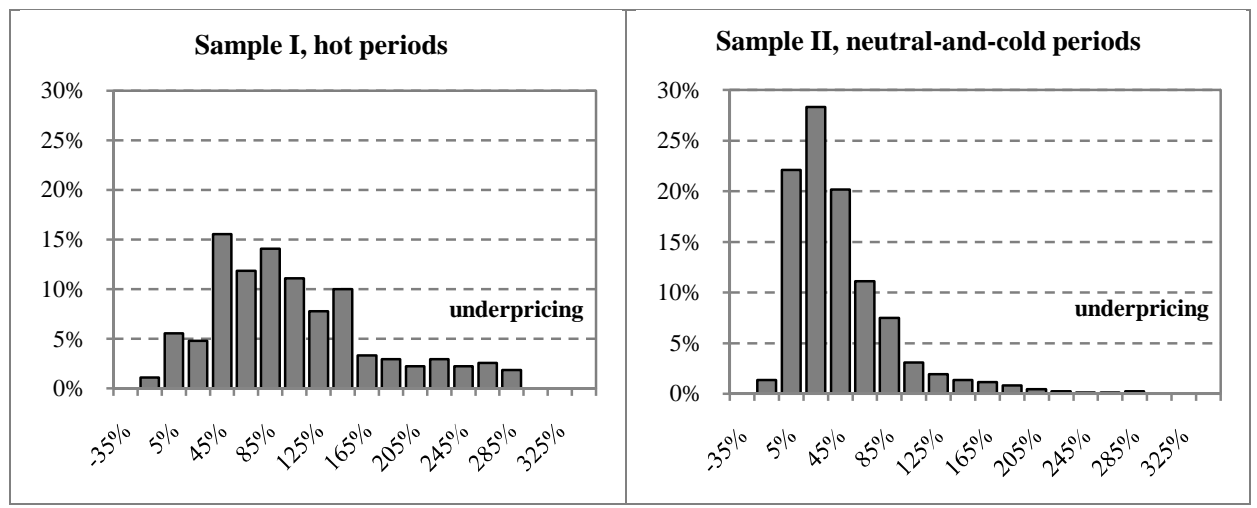

Figure 3. Hot, and neutral-and-cold market underpricing distributions during 2005-2012 Source: own calculations.

The distribution plotted in Figure 3 indicated that the first-day return distributions were positively skewed for both subsamples. However, the returns for the hot period IPOs paralleled the normal distribution to a larger extent. The return distributions were highly non-normal for IPOs completed during the cold-and-neutral period (Sample II).

The underpricing level and two- and four-week returns were significantly higher for hot market IPOs. The mean (median) underpricing and short-term returns were around 3 (4) times as high for Sample I than reported for issues offered during cold-and-neutral periods.

\section{DETERMINANTS OF IPO UNDERPRICING}

Table 6 reports regression results for the whole sample of IPOs from 2005 to 2012, involving proxies for ex-ante uncertainty, signaling games and IPO timing. 
Table 5. Short-term returns in hot (Sample I) versus neutral-and-cold (Sample II) periods

\begin{tabular}{|c|c|c|c|c|}
\hline \multirow{2}{*}{ Panel A: First-day returns } & \multicolumn{2}{|c|}{ Sample I } & \multicolumn{2}{|c|}{ Sample II } \\
\hline & & & & \\
\hline Mean $[\%]$ & 93.02 & & 34.06 & \\
\hline Median [\%] & 80.65 & & 23.34 & \\
\hline$\%<0$ & 6 & & 17 & \\
\hline$\% \geq 0$ & 94 & & 83 & \\
\hline Standard deviation $[\%]$ & 68.42 & & 42.05 & \\
\hline Skewness & 0.83 & & 1.96 & \\
\hline Kurtosis & 0.26 & & 5.49 & \\
\hline Observations & 270 & & 882 & \\
\hline Student t-test (p-val) & 0.0000 & $* * *$ & 0.0000 & $* * *$ \\
\hline Wilcoxon test (p-val) & 0.0001 & $* * *$ & 0.0001 & $* * *$ \\
\hline Jarque Bera test (p-val) & 0.0005 & $* * *$ & 0.0000 & $* * *$ \\
\hline Student t-test for difference (p-val) & 0.0000 & $* * *$ & & \\
\hline Mann Whitney test for difference (p-val) & 0.0001 & $* * *$ & & \\
\hline \multicolumn{5}{|l|}{ Panel B: Two-week returns } \\
\hline Mean $[\%]$ & 66.82 & & 26.21 & \\
\hline Median [\%] & 54.55 & & 14.84 & \\
\hline$\%<0$ & 14 & & 28 & \\
\hline$\% \geq 0$ & 86 & & 72 & \\
\hline Standard deviation $[\%]$ & 63.71 & & 42.26 & \\
\hline Skewness & 0.78 & & 1.75 & \\
\hline Kurtosis & 0.14 & & 4.32 & \\
\hline Observations & 450 & & 1,048 & \\
\hline Student t-test (p-val) & 0.0000 & $* * *$ & 0.0000 & $* * *$ \\
\hline Wilcoxon test (p-val) & 0.0001 & $* * *$ & 0.0001 & $* * *$ \\
\hline Jarque Bera test (p-val) & 0.0000 & $* * *$ & 0.0000 & $* * *$ \\
\hline Student t-test for difference (p-val) & 0.0000 & $* * *$ & & \\
\hline Mann Whitney test for difference ( $\mathrm{p}$-val) & 0.0001 & $* * *$ & & \\
\hline \multicolumn{5}{|l|}{ Panel C: Four-week returns } \\
\hline Mean $[\%]$ & 61.30 & & 22.61 & \\
\hline Median [\%] & 53.25 & & 12.41 & \\
\hline$\%<0$ & 19 & & 32 & \\
\hline$\% \geq 0$ & 81 & & 68 & \\
\hline Standard deviation $[\%]$ & 66.34 & & 41.85 & \\
\hline Skewness & 0.71 & & 1.74 & \\
\hline Kurtosis & -0.07 & & 4.58 & \\
\hline Observations & 538 & & 1,076 & \\
\hline Student t-test (p-val) & 0.0000 & $* * *$ & 0.0000 & $* * *$ \\
\hline Wilcoxon test (p-val) & 0.0001 & $* * *$ & 0.0001 & $* * *$ \\
\hline Jarque Bera test (p-val) & 0.0000 & $* * *$ & 0.0000 & $* * *$ \\
\hline Student t-test for difference (p-val) & 0.0000 & $* * *$ & & \\
\hline Mann Whitney test for difference (p-val) & 0.0001 & $* * *$ & & \\
\hline
\end{tabular}

Note: significance at the 1 percent $(* * *)$ level.

Source: own calculations. 
Table 6. Determinants of underpricing for IPOs during 2005-2012

\begin{tabular}{|c|c|c|c|c|c|c|c|c|}
\hline & OLS_1 & & OLS_2 & & OLS_3 & & OLS_4 & \\
\hline \multirow[t]{2}{*}{ PROC } & $-2,064.49$ & & $-2,085.08$ & & $-2,044.55$ & & $-2,148.81$ & \\
\hline & $(0.0000)$ & $* * *$ & $(0.0000)$ & $* * *$ & $(0.0000)$ & $* * *$ & $(0.0000)$ & $* * *$ \\
\hline \multirow[t]{2}{*}{ A } & $1,855.27$ & & $2,444.40$ & & $2,094.59$ & & $2,491.76$ & \\
\hline & $(0.0000)$ & $* * *$ & $(0.0000)$ & $* * *$ & $(0.0000)$ & $* * *$ & $(0.0000)$ & $* * *$ \\
\hline \multirow[t]{2}{*}{ ROA } & $17,016.45$ & & $18,884.56$ & & $17,782.49$ & & $18,394.34$ & \\
\hline & & & & & $(0.0000)$ & $* * *$ & $(0.0000)$ & $* * *$ \\
\hline \multirow[t]{2}{*}{ ROS } & & & & & -638.47 & & 863.43 & \\
\hline & & & & & $(0.7063)$ & & (0.6889) & \\
\hline \multirow[t]{2}{*}{ ZM_NI } & 359.12 & & & & 106.28 & & 209.14 & \\
\hline & $(0.0105)$ & $* *$ & & & $(0.6767)$ & & (0.4974) & \\
\hline \multirow[t]{2}{*}{ VOL } & $104,560.57$ & & $122,895.67$ & & $99,619.35$ & & $121,878.05$ & \\
\hline & $(0.0000)$ & $* * *$ & $(0.0000)$ & $* * *$ & $(0.0000)$ & $* * *$ & $(0.0000)$ & $* * *$ \\
\hline \multirow[t]{2}{*}{ AGE } & & & 26.08 & & -2.60 & & 25.69 & \\
\hline & & & $(0.1360)$ & & $(0.8379)$ & & $(0.1463)$ & \\
\hline \multirow[t]{2}{*}{ LEV } & $-1,631.76$ & $*$ & $-2,023.38$ & & $-2,491.02$ & & $-2,074.40$ & \\
\hline & (0.0874) & & (0.0970) & $*$ & (0.0107) & $* *$ & (0.0907) & \\
\hline \multirow[t]{2}{*}{ SEO } & $2,123.24$ & & $3,597.32$ & & $2,193.83$ & & $3,606.11$ & \\
\hline & $(0.0000)$ & $* * *$ & $(0.0000)$ & $* * *$ & $(0.0000)$ & $* * *$ & $(0.0000)$ & $* * *$ \\
\hline \multirow[t]{2}{*}{ PREV_UND } & -12.12 & & -29.70 & & -11.80 & & -29.88 & \\
\hline & $(0.0009)$ & $* * *$ & $(0.0021)$ & $* * *$ & $(0.0051)$ & $* * *$ & $(0.0023)$ & $* * *$ \\
\hline \multirow[t]{2}{*}{ WORLD_LR } & $471,816.90$ & & $557,060.20$ & & 448094.09 & & $558,100.54$ & \\
\hline & $(0.0017)$ & $* * *$ & $(0.0038)$ & $* * *$ & $(0.0054)$ & $* * *$ & $(0.0039)$ & $* * *$ \\
\hline \multirow[t]{2}{*}{ REGION_SR } & $157,447.24$ & & & & $70,228.57$ & & $-38,364.05$ & \\
\hline & $(0.0352)$ & ** & & & $(0.3955)$ & & $(0.7265)$ & \\
\hline \multirow[t]{2}{*}{ TIMING } & & & $1,380.54$ & & 814.15 & & $1,420.12$ & \\
\hline & & & $(0.0019)$ & $* * *$ & $(0.0678)$ & & $(0.0044)$ & $* * *$ \\
\hline \multirow[t]{2}{*}{ Constant } & $-3,601.46$ & & $-6,027.71$ & & $-4,171.58$ & & $-6,250.48$ & \\
\hline & $(0.0019)$ & $* * *$ & $(0.0000)$ & $* * *$ & $(0.0004)$ & $* * *$ & $(0.0000)$ & $* * *$ \\
\hline $\mathrm{R}^{2}$ adjusted & 0.40 & & 0.37 & & 0.40 & & 0.37 & \\
\hline F-statistic & 53.40 & $* * *$ & 49.76 & $* * *$ & 42.21 & $* * *$ & 38.22 & $* * *$ \\
\hline Observations & 783 & & 841 & & 791 & & 841 & \\
\hline
\end{tabular}

Note: significance at the 1 percent $(* * *)$ level.

Source: own calculations.

In regressions OLS_1 and OLS_2, most of the proxies showed significant explanatory power for first-day returns. We found that underpricing was positively related to uncertainty proxies, such as size, return on assets, net income change around the IPO date, and return volatility in the early aftermarket. The IPO proceeds showed the opposite sign to that expected by ex-ante uncertainty theory. The return on sales and the age of the company at the IPO date appeared to be insignificant.

The results also support the proposition that underpricing was related to signaling probability. Underpricing appeared to be a kind of appetizer for 
potential investors in subsequent equity offerings, as the initial returns were reported to be higher for IPO companies that placed seasoned equity offerings just after the first public listing. However, the higher the leverage and the more restrictions imposed on managers to limit their latitude to control cash flow by higher leverage, the lower the underpricing seemed to be.

The timing proxies were documented to be significant. We reported a positive relation between underpricing and both long-term world positive investor sentiment and short-term positive market returns in the region. The previous underpricing level seems to have had the opposite influence on underpricing to the one expected.

Table 7. Determinants of underpricing for IPOs during hot periods (Sample I)

\begin{tabular}{|c|c|c|c|c|c|c|c|c|}
\hline & OLS_1 & & OLS_2 & & OLS_3 & & OLS_4 & \\
\hline \multirow[t]{2}{*}{ PROC } & $-2,103.00$ & & & & $-1,761.00$ & & $-1,255.00$ & \\
\hline & $(0.0171)$ & $* *$ & & & $(0.0811)$ & & $(0.2467)$ & \\
\hline \multirow[t]{2}{*}{ A } & $4,147.00$ & & $3,840.00$ & & $4,120.00$ & & $4,556.00$ & \\
\hline & $(0.0000)$ & $* * *$ & $(0.0000)$ & $* * *$ & $(0.0000)$ & $* * *$ & $(0.0000)$ & $* * *$ \\
\hline \multirow{2}{*}{ ROA } & $44,930.00$ & & $27,620.00$ & & $34,960.00$ & & $31,770.00$ & \\
\hline & $(0.0000)$ & $* * *$ & $(0.0022)$ & $* * *$ & $(0.0062)$ & $* * *$ & $(0.0277)$ & $* *$ \\
\hline \multirow[t]{2}{*}{ ROS } & & & & & $3,648.00$ & & $1,253.00$ & \\
\hline & & & & & $(0.6371)$ & & $(0.8883)$ & \\
\hline \multirow[t]{2}{*}{ ZM_NI } & & & & & 9.38 & & -700.10 & \\
\hline & & & & & (0.9920) & & $(0.4015)$ & \\
\hline \multirow[t]{2}{*}{ VOL } & $171,800.00$ & & $182,700.00$ & & $187,000.00$ & & $166,800.00$ & \\
\hline & $(0.0000)$ & $* * *$ & $(0.0000)$ & $* * *$ & $(0.0000)$ & $* * *$ & $(0.0001)$ & $* * *$ \\
\hline \multirow[t]{2}{*}{ AGE } & & & 80.83 & & 7.74 & & 69.81 & \\
\hline & & & $(0.1071)$ & & $(0.8609)$ & & $(0.1741)$ & \\
\hline \multirow[t]{2}{*}{ LEV } & & & & & $-1,141.00$ & & 98.69 & \\
\hline & & & & & $(0.7517)$ & & $(0.9807)$ & \\
\hline \multirow[t]{2}{*}{ SEO } & $1,965.00$ & & $3,119.00$ & & $1,887.00$ & & $2,799.00$ & \\
\hline & $(0.0798)$ & $*$ & $(0.0129)$ & $* *$ & $(0.1133)$ & & $(0.0349)$ & $* *$ \\
\hline \multirow[t]{2}{*}{ PREV_UND } & -48.52 & & -48.24 & & -35.09 & & -49.17 & \\
\hline & $(0.0006)$ & $* * *$ & $(0.0010)$ & $* * *$ & $(0.0132)$ & ** & $(0.0012)$ & $* * *$ \\
\hline \multirow[t]{2}{*}{ WORLD_LR } & $-1,974,000.00$ & & $-2,554000.00$ & & $-805,300.00$ & & $-2,017000.00$ & \\
\hline & $(0.0121)$ & $* *$ & $(0.0009)$ & $* * *$ & $(0.2624)$ & & $(0.0259)$ & $* *$ \\
\hline \multirow[t]{2}{*}{ REGION_SR } & & & & & -3079.00 & & -267700.00 & \\
\hline & & & & & (0.9924) & & $(0.4549)$ & \\
\hline \multirow[t]{2}{*}{ Constant } & $-11,950.00$ & & $-17,740.00$ & & $-15,180.00$ & & $-14,860.00$ & \\
\hline & $(0.0025)$ & $* * *$ & $(0.0001)$ & $* * *$ & $(0.0017)$ & $* * *$ & $(0.0051)$ & $* * *$ \\
\hline $\mathrm{R}^{2}$ adjusted & 0.42 & & 0.40 & & 0.38 & & 0.39 & \\
\hline F-statistic & 19.85 & $* * *$ & 19.55 & $* * *$ & 10.35 & $* * *$ & 11.49 & $* * *$ \\
\hline Observations & 180 & & 197 & & 181 & & 197 & \\
\hline
\end{tabular}

Note: significance at the 1 percent $(* * *)$ level and 5 percent $(* *)$ level.

Source: own calculations. 
We also ran the regressions for the subsamples differentiated by the market regime at the time of flotation. Table 7 and Table 8 report the regression estimates for the subsample of hot- and cold-and-neutral market IPOs, respectively.

Table 8. Determinants of underpricing for IPOs during neutral and cold periods (Sample II)

\begin{tabular}{|c|c|c|c|c|c|c|c|c|}
\hline & OLS_1 & & OLS_2 & & OLS_3 & & OLS_4 & \\
\hline PROC & $\begin{array}{r}-2,210.67 \\
(0.0000)\end{array}$ & $* * *$ & $\begin{array}{r}-2,096.50 \\
(0.0000)\end{array}$ & $* * *$ & $\begin{array}{r}-2,269.19 \\
(0.0000)\end{array}$ & $* * *$ & $\begin{array}{r}-2,080.27 \\
(0.0000)\end{array}$ & $* * *$ \\
\hline A & $\begin{array}{l}1,364.70 \\
(0.0000)\end{array}$ & $* * *$ & $\begin{array}{l}1,396.10 \\
(0.0000)\end{array}$ & $* * *$ & $\begin{array}{l}1,435.72 \\
(0.0000)\end{array}$ & $* * *$ & $\begin{array}{l}1,379.63 \\
(0.0000)\end{array}$ & $* * *$ \\
\hline ROA & $12,925.08$ & & $14,340.20$ & & $14,094.95$ & & $14,221.24$ & \\
\hline ROS & $(0.0000)$ & $* * *$ & $(0.0000)$ & $* * *$ & $\begin{array}{r}(0.0000) \\
-972.54 \\
(0.4043)\end{array}$ & $* * *$ & $\begin{array}{r}(0.0000) \\
-257.37 \\
(0.8609)\end{array}$ & $* * *$ \\
\hline ZM_NI & $\begin{array}{r}496.08 \\
(0.0209)\end{array}$ & $* *$ & $\begin{array}{r}615.00 \\
(0.0052)\end{array}$ & $* * *$ & $\begin{array}{r}517.14 \\
(0.0123)\end{array}$ & $* *$ & $\begin{array}{r}611.65 \\
(0.0057)\end{array}$ & $* * *$ \\
\hline VOL & $\begin{array}{r}45500.63 \\
(0.0000)\end{array}$ & $* * *$ & $\begin{array}{r}58764.70 \\
(0.0000)\end{array}$ & $* * *$ & $\begin{array}{r}37613.33 \\
(0.0000)\end{array}$ & $* * *$ & $\begin{array}{r}57218.79 \\
(0.0000)\end{array}$ & $* * *$ \\
\hline AGE & & & & & $\begin{array}{r}2.66 \\
(0.7850)\end{array}$ & & $\begin{array}{r}8.61 \\
(0.5056)\end{array}$ & \\
\hline LEV & & & & & $\begin{array}{r}230.55 \\
(0.7458)\end{array}$ & & $\begin{array}{l}-613.12 \\
(0.4762)\end{array}$ & \\
\hline SEO & $\begin{array}{l}1,549.24 \\
(0.0000)\end{array}$ & $* * *$ & $\begin{array}{l}2,526.20 \\
(0.0000)\end{array}$ & $* * *$ & $\begin{array}{l}1,454.38 \\
(0.0000)\end{array}$ & $* * *$ & $\begin{array}{r}2,504.07 \\
(0.0000)\end{array}$ & $* * *$ \\
\hline PREV_UND & $\begin{array}{r}-5.39 \\
(0.1336)\end{array}$ & & & & $\begin{array}{r}-4.71 \\
(0.1651)\end{array}$ & & $\begin{array}{r}3.33 \\
(0.4785)\end{array}$ & \\
\hline WORLD_LR & $\begin{array}{r}524,489.89 \\
(0.0000)\end{array}$ & $* * *$ & $\begin{array}{r}535,659.00 \\
(0.0000)\end{array}$ & $* * *$ & $\begin{array}{r}547909.11 \\
(0.0000)\end{array}$ & $* * *$ & $\begin{array}{r}535,786.42 \\
(0.0001)\end{array}$ & $* * *$ \\
\hline REGION_SR & $\begin{array}{r}142,707.99 \\
(0.0277)\end{array}$ & $* *$ & $\begin{array}{r}163,059.40 \\
(0.0230)\end{array}$ & $* *$ & $\begin{array}{r}139558.01 \\
(0.0254)\end{array}$ & $* *$ & $\begin{array}{r}178,157.53 \\
(0.0182)\end{array}$ & $* *$ \\
\hline Constant & $\begin{array}{r}655.51 \\
(0.4754)\end{array}$ & & $\begin{array}{l}-828.70 \\
(0.4104)\end{array}$ & & $\begin{array}{r}717.14 \\
(0.4365)\end{array}$ & & $\begin{array}{l}-863.38 \\
(0.4315)\end{array}$ & \\
\hline $\mathrm{R}^{2}$ adjusted & 0.50 & & 0.49 & & 0.52 & & 0.49 & \\
\hline F-statistic & 67.81 & $* * *$ & 77.78 & $* * *$ & 54.84 & $* * *$ & 51.78 & $* * *$ \\
\hline Observations & 598 & & 644 & & 597 & & 644 & \\
\hline
\end{tabular}

Note: significance at the 1 percent $(* * *)$ level and 5 percent $(* *)$ level.

Source: own calculations.

All of the significant explanatory variables for hot, and cold-and-neutral market IPOs were related in a similar way to underpricing, except for the long-term world market situation. However, not all of the proxies were significant in the regressions run for both subsamples. The higher the change of net income around the listing date, the higher the reported underpricing for the cold-and- 
-neutral market offerings. One of the reasons for this might be the increased importance of 'good news' (such as the earnings increase) in bearish periods. Next, the regional market situation just around the IPO date appeared to be important in lukewarm periods. Neither of these two relations was observed for hot market IPOs.

\section{CONCLUSION}

There were extremely high initial, two- and four-week returns reported for initial public offerings (IPOs) in the three top emerging markets from 2005 to 2012. The highest level of short-term returns was reported for China. The results pointed to the existence of significant differences in IPO short-term returns between the initial equity issues offered in hot, and cold-and-neutral markets.

Regressions were applied to verify if the ex-ante uncertainty, signaling games and timing had the explanatory power for IPO first-day returns during the sample period. The study documented that the amount of money left on the table during initial public offerings was related most to the uncertainty, signaling and timing proxies. It can be concluded that underpricing could be considered as an additional fee paid to investors for the high level of uncertainty at the time of issue. It could also be treated as a kind of branding method to attract possible investors by leaving a good taste in investors' mouths for future equity issues. IPO timing seemed to be of high importance in explaining underpricing.

Concerning the findings of regressions that were run for the subsamples suited according to the market trends around the IPO date, we may conclude that there were proxies that differentiated hot, and cold-and-neutral market IPOs.

The study suggests that the reported huge underpricing for the three top emerging markets could also be explained with models based on stakeholder rationality as those concerning behavioral factors, particularly investor sentiment. However, the debate on the reasons behind underpricing should be continued in the future.

\section{REFERENCES}

Allen F., Faulhaber G. R., 1989, Signalling by underpricing in the IPO market, Journal of Financial Economics 23(2), 303-323.

Baker M., Wurgler J., 2002, Market timing and capital structure, Journal of Finance 57(1), 1-32.

Beatty R. P., Ritter J. R., 1986, Investment banking, reputation, and the underpricing of initial public offerings, Journal of Financial Economics 15(1), 213-232.

Derrien F., 2005, IPO pricing in 'hot' market conditions: Who leaves money on the table?, Journal of Finance 60(1), 487-521. 
Ghosh S., 2005, Underpricing of initial public offerings: the Indian experience, Emerging Markets Finance and Trade 41(6), 45-57.

Harris M., Raviv A., 1990, Capital structure and the informational role of debt, Journal of Finance 45(2), 321-349.

Ibbotson R. G., 1975, Price performance of common stock new issues, Journal of Financial Economics 2(3), 235-272.

Jegadeesh N., Weinstein M., Welch I., 1993, An empirical investigation of IPO returns and subsequent equity offerings, Journal of Financial Economics 34(2), 153-175.

Lee J. S., Kuo C. T., Yen P. H., 2011, Market states and initial returns: Evidence from Taiwanese IPOs, Emerging Markets Finance and Trade 47(2), 6-20.

Lin C. Y., Lee H. T., Lee C. L., 2008, One More Step, Some More Performance? An Empirical Study on Initial Public Offerings in the Taiwan Emerging Stock Market, Emerging Markets Finance and Trade 44(4), 6-18.

Ljungqvist A. P., 1997, Pricing initial public offerings: Further evidence from Germany, European Economic Review 41(7), 1309-1320.

Loughran T., Ritter J. R., 1995, The new issues puzzle, Journal of Finance 50(1), 23-51.

Lowry M., Schwert G. W., 2002, IPO market cycles: Bubbles or sequential learning?, Journal of Finance 57(3), 1171-1200.

McGuinness P., 1992, An examination of the underpricing of initial public offerings in Hong Kong: 1980-90, Journal of Business Finance \& Accounting 19(2), 165-186.

Nachman D. C., Noe T. H., 1994, Optimal design of securities under asymmetric information, Review of Financial Studies 7(1), 1-44.

Oehler A., Rummer M., Smith P. N., 2008, Is the Investor Sentiment Approach the Solution to the IPO Underpricing Phenomenon?, Available at SSRN 1286842.

Pastor-Llorca M. J., Poveda-Fuentes F., 2006, Earnings management and the long-run performance of Spanish initial public offerings. Initial Public Offerings: An International Perspective, Elsevier Butterworth-Heinemann, 81-112.

Rajan R., Servaes H., 1997, Analyst following of initial public offerings, Journal of Finance 52(2), $507-529$.

Ritter J. R., 1984, The 'hot issue' market of 1980, Journal of Business, 215-240.

Rock K., 1986, Why new issues are underpriced, Journal of Financial Economics 15(1), 187-212.

Roosenboom P., van der Goot T., Mertens G., 2003, Earnings management and initial public offerings: evidence from the Netherlands, International Journal of Accounting 38(3), 243-266.

Teoh S. H., Welch I., Wong T. J., 1998, Earnings management and the long-run market performance of initial public offerings, Journal of Finance 53(6), 1935-1974.

Joanna Lizińska, Leszek Czapiewski

\section{CZY TEORIA WYCZUCIA RYNKU WYJAŚNIA KRÓTKOOKRESOWĄ REAKCJĘ CENOWĄ TOWARZYSZĄCĄ EMISJOM IPO? - DOŚWIADCZENIA NAJWIĘKSZYCH RYNKÓW WSCHODZĄCYCH}

Badania, których rezultaty zawiera opracowanie koncentrowały się wokół oceny krótkookresowej reakcji cenowej następującej po debiucie giełdowym (IPO). Próba badawcza obejmowała spółki dokonujące pierwotnej emisji akcji na jednym z trzech głównych rynków wschodzących w okresie 2005-2012. Celem artykułu było wyjaśnienie, czy krótkoterminowe niedoszacowanie cen akcji debiutujących spółek można wyjaśnić odwołując się do modeli opartych na racjonalności czy na aspektach behawioralnych. 
W okresie badawczym dla ofert dokonywanych na głównych rynkach wschodzących zaobserwowano wysoki poziom krótkoterminowych stóp zwrotu. Odnotowano również istotne statystycznie różnice $\mathrm{w}$ poziomie stóp zwrotu w podokresach wyróżnionych ze względu na koniunkturę rynkową. $Z$ badań wynika również, iż krótkookresowa reakcja cenowa towarzysząca debiutom giełdowym była związana z poziomem niepewności, czynnikami odnoszącymi się do sygnalizacji oraz do teorii wyczucia rynku (market timing).

Słowa kluczowe: pierwotne emisje akcji, underpricing, asymetria informacji, teoria market timing. 